\title{
Serotonin Receptors in Suicide Victims with Major Depression
}

\author{
Craig A. Stockmeier, Ph.D., Ginny E. Dilley, B.A., Laura A. Shapiro, B.S., \\ James C. Overholser, Ph.D., Paul A. Thompson, Ph.D., and Herbert Y. Meltzer, M.D.
}

Serotonin $_{1 A}\left(5-H T_{1 A}\right)$ and serotonin sA $_{2}\left(5-H T_{2 A}\right)$ receptors in the brain have been implicated in the pathophysiology of suicide. Brain samples were collected at autopsy from suicide victims with a current episode of major depression and matched comparison subjects who died of natural or accidental causes. Retrospective psychiatric assessments were collected from knowledgeable informants for all suicide victims and most of the comparison subjects. Psychiatric diagnoses were determined according to DSM-III-R criteria. Any subjects with current psychoactive substance use disorders were excluded. Quantitative receptor autoradiography was used in serial sections of the right prefrontal cortex (area 10) and hippocampus to measure the binding of $\left[{ }^{3} \mathrm{H}\right] 8$-hydroxy-2-(di-n-propyl)-aminotetralin $\left(\left[{ }^{3} \mathrm{H}\right] 8-\mathrm{OH}-\mathrm{DPAT}\right)$ to $5-\mathrm{HT} \mathrm{T}_{1 \mathrm{~A}}$ receptors and $\left[{ }^{3} \mathrm{H}\right]$ ketanserin to $5-H T_{2 A}$ receptors. Analysis of covariance was used to compare control subjects and suicide victims with major depression. The age of subjects, the time from death to freezing the tissue (postmortem interval), and the storage time of tissues in the freezer were used as covariates in the analyses. There were no significant differences between suicide victims with major depression and comparison subjects in $5-H T_{1 A}$ or $5-H T_{2 A}$ receptors in area 10 of the right prefrontal cortex or the hippocampus. The current results suggest that the number of $5-H T_{1 A}$ and $5-H T_{2 A}$ receptors in the right prefrontal cortex (area 10) or hippocampus are not different in suicide victims with major depression.

(C) 1997 American College of Neuropsychopharmacology [Neuropsychopharmacology 16:162-173, 1996]
KEY WORDS: Suicide; Major depression; Serotonin ${ }_{1 A}$ receptor; Serotonin $2 A$ receptor; Prefrontal cortex; Hippocampus

Over three decades of research and clinical observations have strengthened the hypothesis that a decrease in serotonergic activity is involved in the etiology of depression and suicide and that antidepressant drugs act, in part, by increasing serotonergic neurotransmission (Coppen 1967; Blier and de Montigny 1994). Evidence

From the Departments of Psychiatry (CAS, GED, LAS, PAT, HYM), Neuroscience (CAS); and Psychology (JCO), School of Medicine, Case Western Reserve University, Cleveland, Ohio.

Address correspondence to: Craig A. Stockmeier, Ph.D., Department of Psychiatry, University Hospitals of Cleveland, 11100 Euclid Avenue, Cleveland, $\mathrm{OH} 44106$.

Received January 10, 1996; revised June 25, 1996; accepted July $18,1996$. for a decrease in serotonin neurotransmission in major depression comes from clinical observations that the symptoms of depression are relieved by chronic treatment with drugs that either block the reuptake or metabolism of serotonin or otherwise potentiate serotonergic activity (Grimsley and Jann 1993). Other studies supporting this hypothesis reveal that depletion of serotonin with $p$-chlorophenylalanine or a tryptophan-deficient diet results in the recurrence of depressive symptoms in subjects who have recovered from depression due to treatment with specific antidepressant drugs (Shopsin et al. 1975; Delgado et al. 1990). In addition, in some postmortem studies, suicide victims are reported to have a lower concentration of serotonin or its metabolite, 5-hydroxyindoleacetic acid, in the brainstem, than control subjects (reviewed by Asberg 1987). This evidence forms part of the hypothesis that decreased serotonin-related neurotransmission appears to be linked to the pathophysiology of 
major depression and suicide and that the mechanism of action of some antidepressant treatments may be to enhance serotonergic activity.

In light of the hypothesis that serotonin mechanisms are altered in mood disorders, it has been suggested that the number of serotonin receptors in the human forebrain may be lower in suicide victims than in nonsuicide controls. Several studies have examined radioligand binding to postsynaptic serotonin ${ }_{1 \mathrm{~A}}\left(5-\mathrm{HT}_{1 \mathrm{~A}}\right)$ and serotonin ${ }_{2 \mathrm{~A}}$ $\left(5-\mathrm{HT}_{2 \mathrm{~A}}\right)$ receptors in postmortem brain tissue of suicide victims. For example, $5-\mathrm{HT}_{2 \mathrm{~A}}$ receptors were reported to be higher in suicide victims in five studies (Stanley et al. 1983; Mann et al. 1986; Arora and Meltzer 1989; Arango et al. 1990; Hrdina et al. 1993), lower in one study (GrossIsseroff et al. 1990), and unchanged in six studies (Owen et al. 1983, 1986; Crow et al. 1984; Cheetham et al. 1988; Low ther et al. 1994; Arranz et al. 1994). No clear picture has emerged, however, because there are a number of significant differences between these studies with regard to: (1) the psychiatric status of the suicide victims at the time of death, including the underlying psychiatric disorder; (2) the diagnostic criteria used to establish the psychiatric diagnosis in several of the studies; (3) the exclusion of subjects with current psychoactive substance use disorders; (4) the brain region examined; (5) the presence and duration of treatment with antidepressant drugs of various classes; and (6) the methodology to quantify $5-\mathrm{HT}_{1 \mathrm{~A}}$ and $5-\mathrm{HT}_{2 \mathrm{~A}}$ receptors.

The purpose of this study was to use quantitative receptor autoradiography to examine the hypothesis that the number of $5-\mathrm{HT}_{1 \mathrm{~A}}$ and $5-\mathrm{HT}_{2 \mathrm{~A}}$ receptors would be higher in the right prefrontal cortex (area 10) and hippocampus of suicide victims with major depression than in psychiatrically normal control subjects. Suicide victims met criteria for current major depression as defined by the Diagnostic and Statistic Manual of Mental Disorders-Revised (DSM-III-R; American Psychiatric Association 1987).

\section{MATERIALS AND METHODS}

\section{Subjects}

Brain tissue was obtained at autopsy at the Cuyahoga County (Ohio) Coroner's Office. The study was performed in compliance with the policies of an institutional review board, and written consent was obtained from the next-of-kins. Tissue samples were collected from 13 suicide victims with major depression and 15 comparison subjects who died of natural or accidental causes. Only subjects with an agonal state of 1 hour or less were chosen. The causes of death were certified by the County Coroner and are listed in Table 1.

Blood and urine samples from all of the subjects were examined by the toxicology laboratory of the County Coroner's Office. Qualitative and quantitative assays were used to detect the following compounds or classes of compounds: antidepressant and antipsychotic drugs and their metabolites, ethanol, barbiturates, benzodiazepines, sympathomimetic amines, cocaine, and cocaine metabolites, opiates, phencyclidine, cannabinoids, and antiepileptic drugs. The results of the toxicology testing for suicide and control subjects are described in Table 1. An antidepressant drug (imipramine and its metabolite desipramine) and cocaine were detected in the blood from one suicide victim. However, this subject did not meet diagnostic criteria for a psychoactive substance use disorder. This subject was excluded from the $5-\mathrm{HT}_{2 \mathrm{~A}}$ receptor studies because these antidepressant drugs have relatively high affinity for this receptor, but this subject was included in the $5-\mathrm{HT}_{1 \mathrm{~A}}$ receptor studies because these antidepressant drugs have low affinity for this receptor $\left(\sim 200 \mathrm{nM}\right.$ and $6 \mu \mathrm{m}$ at the $5-\mathrm{HT}_{2 \mathrm{~A}}$ and $5-\mathrm{HT}_{1 \mathrm{~A}}$ receptors, respectively [Cusack et al. 1994]). Although ethanol was detected in blood samples from two subjects $(0.04 \%$ and $0.19 \%)$, neither of these subjects met criteria for alcohol abuse or dependence. One suicide victim had a medical history of Parkinson's disease.

In the prefrontal cortex, 5- $\mathrm{HT}_{1 \mathrm{~A}}$ receptors were measured in 13 of the 15 control subjects and all 13 suicide victims, and $5-\mathrm{HT}_{2 \mathrm{~A}}$ receptors were measured in 9 of the control subjects and 10 of the suicide victims. In the hippocampus, $5-\mathrm{HT}_{1 \mathrm{~A}}$ and $5-\mathrm{HT}_{2 \mathrm{~A}}$ receptors were measured in 10 of the control subjects and 10 of the suicide victims.

\section{Retrospective Psychiatric Assessments}

We used retrospective psychiatric assessments to identify control subjects without mental illness and suicide victims with a current diagnosis of major depression. Any subjects with current psychoactive substance use disorders were excluded. Three to six months after death, a trained interviewer administered a face-to-face interview with a knowledgeable informant for all 13 suicide victims to collect information to determine the presence of Axis I psychiatric disorders. Knowledgeable informants also were interviewed for 12 of the 15 control subjects. Knowledgeable informants either lived with or had frequent weekly contact with the subjects prior to death. For suicide victims and psychiatrically normal comparison subjects, respectively, the knowledgeable informants were: spouse $(50 \%, 75 \%)$, parent $(36 \%, 0 \%)$, sibling $(7 \%, 25 \%)$, adult child $(43 \%, 42 \%)$, or other relative $(0 \%, 17 \%)$. There was more than one key respondent in four suicide and four control cases. Data on lifetime and current mental illness were gathered with a modified Schedule for Affective Disorders and Schizophrenia; lifetime version (SADS-L; Spitzer and Endicott, 1978). The SADS has demonstrated adequate validity in comparing patient-based and knowledgeable informant-based information and has been used in research on suicide (Andreasen et al. 1977; Arató et al. 1988; Lesage et al. 1994). 
Table 1. Characteristics of Subjects

\begin{tabular}{|c|c|c|c|c|c|}
\hline Age/Sex & PMI & $\begin{array}{l}\text { Cause of } \\
\text { Death }\end{array}$ & $\begin{array}{l}\text { DSM-III-R } \\
\text { Axis I } \\
\text { Diagnosis }^{a}\end{array}$ & Toxicology & Medication History \\
\hline \multicolumn{6}{|c|}{ Suicide victims } \\
\hline $22 / \mathrm{M}$ & 18 & Hanging & MD; dysthymia & $\begin{array}{l}\text { Cocaine, Desipramine, } \\
\text { Imipramine }\end{array}$ & Imipramine $e^{\mathrm{b}}$ \\
\hline $25 / F$ & 17 & Hanging & MD & Nothing detected & Perphenazine $^{b}$, Nortriptyline $^{b}$ \\
\hline $38 / \mathrm{F}$ & 12 & Overdose & MD & $\begin{array}{l}\text { Acetaminophen, } \\
\text { Temazepam } \\
\text { Diazepam, } \\
\text { lidocaine }\end{array}$ & $\begin{array}{l}\text { Sertraline }{ }^{b}, \text { Temazepam } \\
\quad \text { Propranolol }^{b}\end{array}$ \\
\hline $42 / \mathrm{M}$ & 20 & Gunshot-chest & MD & Nothing detected & None \\
\hline $43 / \mathrm{M}$ & 21 & Hanging & MD & Nothing detected & None \\
\hline $45 / \mathrm{M}$ & 8 & Stab & MD; dysthymia & Nothing detected & None \\
\hline $47 / \mathrm{M}$ & 11 & Gunshot-head & MD & Ethanol, $0.19 \%$ & None \\
\hline $62 / \mathrm{M}$ & 5 & Hanging & MD & Nothing detected & $\begin{array}{l}\text { Trazodone, Nortriptyline, } \\
\text { Sertraline } \\
\text { (all } 6 \text { mo. prior to death) }\end{array}$ \\
\hline $62 / \mathrm{M}$ & 20 & Gunshot-chest & MD & Nothing detected & $\begin{array}{l}\text { Buspirone }{ }^{b}(6 \mathrm{~d} \text { prior to death); } \\
\text { Lorazepam }\end{array}$ \\
\hline $68 / \mathrm{M}^{c}$ & 4 & $\begin{array}{l}\text { Carbon } \\
\text { monoxide }\end{array}$ & MD & Carbon monoxide & Selegiline (probably not taking) \\
\hline $70 / \mathrm{M}$ & 23 & Gunshot-head & MD & Phenytoin-acute & Doxepin (probably not taking) \\
\hline $73 / \mathrm{M}$ & 18 & Gunshot-chest & MD & Diazepam, codeine & $\begin{array}{l}\text { Diazepam }{ }^{b}, \text { Hydroxyzine, } \\
\text { fluoxetine, trazodone }\end{array}$ \\
\hline $83 / \mathrm{F}$ & 21 & Slash & MD & Nothing detected & Temazepam $^{b}$ \\
\hline \multicolumn{6}{|c|}{ Control subjects } \\
\hline $24 / \mathrm{F}$ & 21 & Smoke inhalation & $\begin{array}{l}\text { No information } \\
\text { available }\end{array}$ & Nothing detected & No information available \\
\hline $26 / \mathrm{M}$ & 13 & Gunshot & No diagnosis & Nothing detected & None \\
\hline $40 / \mathrm{M}$ & 22 & Heart disease & No diagnosis & Lidocaine & None \\
\hline $44 / \mathrm{M}$ & 6 & Aneurism & No diagnosis & $\begin{array}{l}\text { Ephedrine, } \\
\text { phenylpropanolamine }\end{array}$ & None \\
\hline $45 / F$ & 9 & Heart disease & No diagnosis & Nothing detected & None \\
\hline $47 / \mathrm{M}$ & 17 & Heart disease & No diagnosis & Nothing detected & Pepsid \\
\hline $50 / \mathrm{M}$ & 26 & Heart disease & No diagnosis & Nothing detected & None \\
\hline $56 / \mathrm{M}$ & 25 & Heart disease & No diagnosis & Nothing detected & None \\
\hline $58 / \mathrm{M}$ & 22 & Heart disease & No diagnosis & Nothing detected & Lanoxin \\
\hline $62 / \mathrm{M}$ & 26 & Heart disease & $\begin{array}{l}\text { No information } \\
\text { available }\end{array}$ & $\begin{array}{l}\text { Lidocaine, } \\
\text { ETOH- } 0.04 \%\end{array}$ & Nitroglycerin \\
\hline $62 / \mathrm{F}$ & 28 & Bike accident & No diagnosis & Nothing detected & None \\
\hline $64 / \mathrm{M}$ & 26 & Heart disease & $\begin{array}{l}\text { No information } \\
\text { available }\end{array}$ & Nothing detected & No information available \\
\hline $71 / \mathrm{M}$ & 23 & Heart disease & No diagnosis & Chlorpheniramine & Nitroglycerin, coumadin \\
\hline $73 / \mathrm{M}$ & 22 & Heart disease & No diagnosis & Nothing detected & None \\
\hline $82 / \mathrm{M}$ & 16 & Aneurism & No diagnosis & Nothing detected & Synthroid \\
\hline
\end{tabular}

"MD, major depression.

${ }^{b}$ Medications prescribed within the last month of life.

'Subject also diagnosed with Parkinson's disease.

Diagnoses for Axis I disorders were independently assessed by a clinical psychologist and psychiatrist, and consensus diagnosis was reached in conference with all available information from the knowledgeable informants, coroner's office, previous hospitalizations, and doctors' records. The final diagnosis was compatible with the DSM-III-R classification. For this study, suicide victims had a current history of major depression during the last month of life. Two suicide victims with major depression also had a current comorbid diagnosis of dysthymia. In addition, two suicide victims previously met DSM-III-R criteria for alcohol abuse and alcohol dependence at 5 and 15 years, respectively, before death. One psychiatrically normal control subject previously met criteria for alcohol abuse 2 years before death. For the three nonsuicide comparison subjects for whom no 
respondent was interviewed, there was no evidence in the coroner's records that these subjects had an Axis I mental illness. The psychiatric diagnoses are summarized in Table 1. Comparably aged sets of suicide victims and comparison subjects (within 10 years) were sectioned, assayed, and analyzed together. Samples were coded to ensure that receptor measurements were not biased by laboratory personnel.

\section{Tissues}

Tissue blocks were dissected from a consistent region on the lateral surface of the anterior pole of the frontal lobe (prefrontal cortex, Brodmann area 10), and the rostral $1.5 \mathrm{~cm}$ of the body of the hippocampus (immediately caudal to the uncus). The blocks were immersed briefly in isopentane cooled in dry ice, completely frozen in powdered dry ice, and stored at $-80^{\circ} \mathrm{C}$ until sectioning. The blocks were mounted on brass pedestals with TissueTek (Miles), and frozen sections $(10 \mu \mathrm{m})$ were cut at $-15^{\circ} \mathrm{C}$ with a microtome (IEC). Sections were thawmounted on to cold microscope slides coated with gelatin/chrom-alum, dried under a stream of room-temperature air and refrozen at $-80^{\circ} \mathrm{C}$. Sections adjacent to those used for autoradiography were stained with cresyl violet for histological reference. Prior to receptor assays, boxes containing slide-mounted sections were removed from the freezer, equilibrated to room temperature, and the tissue sections were warmed under a stream of roomtemperature air.

Additional sections of the prefrontal cortex were stained with hematoxylin and eosin and screened by a board-certified neuropathologist to rule out major pathology. Further studies were done in some subjects with a mouse monoclonal antibody to glial fibrillary acidic protein (GA5, Sigma Chemical) to rule out gliosis, or with 4G8, a monoclonal antibody to $A \beta$ amyloid plaques, to rule out Alzheimer's disease.

\section{Serotonin Receptor Autoradiography}

Radioligand binding to $5-\mathrm{HT}_{2 \mathrm{~A}}$ receptors was determined autoradiographically according to the technique by Hoyer et al. (1986). After a 30-minute preincubation at room temperature in buffer containing $170 \mathrm{mM}$ Tris- $\mathrm{HCl}$, $4 \mathrm{mM} \mathrm{CaCl}_{2}$, and $0.01 \%$ ascorbic acid ( $\mathrm{pH} 7.7$ at room temperature), triplicate sections were incubated in fresh buffer for 1 hour at room temperature with [ $\left.{ }^{3} \mathrm{H}\right] 8$-hydroxy2-(di-n-propyl)-aminotetralin (8-OH-DPAT, 2 nM, 143.8 $\mathrm{Ci} / \mathrm{mmol}$, New England Nuclear, Boston, MA). Nonspecific binding was measured in duplicate serial sections coincubated with $10 \mu \mathrm{M}$ 5-HT (serotonin creatinine sulfate salt, Sigma, St. Louis, MO). Citalopram-hydrobromide ( $1 \mu \mathrm{M}$, Lundbeck, Copenhagen, Denmark) was included in the incubation with $\left[{ }^{3} \mathrm{H}\right] 8-\mathrm{OH}-\mathrm{DPAT}$ because there is evidence in the rat striatum that $\left[{ }^{3} \mathrm{H}\right] 8-\mathrm{OH}-\mathrm{DPAT}$ also binds to the serotonin transporter (Alexander and Wood 1988). After the incubation, the sections were washed twice at $5^{\circ} \mathrm{C}$ for 5 minutes each in the same (nonradioactive) buffer ( $\mathrm{pH} 7.7$ at $4^{\circ} \mathrm{C}$ ).

Radioligand binding to $5-\mathrm{HT}_{2 \mathrm{~A}}$ receptors was determined autoradiographically according to the method of Pazos et al. (1987b). Triplicate sections were incubated in $170 \mathrm{mM}$ Tris-HCl buffer ( $\mathrm{pH} 7.7$ ) for 1 hour at room temperature with $\left[{ }^{3} \mathrm{H}\right]$ ketanserin $(2 \mathrm{nM} ; 85.1 \mathrm{Ci} / \mathrm{mmol}$, New England Nuclear). Nonspecific binding was measured in duplicate serial sections coincubated with $1 \mu \mathrm{M}$ mianserin- $\mathrm{HCl}$ (Research Biochemicals International, Natick, MA). Prazosin-HCl (100 nM; Research Biochemicals International) was included in the incubation to prevent the binding of $\left[{ }^{3} \mathrm{H}\right]$ ketanserin to $\alpha_{1}$-adrenergic receptors (Hoyer et al. 1987). After the incubation, the sections were washed twice at $4^{\circ} \mathrm{C}$ for 20 minutes each in nonradioactive buffer ( $\mathrm{pH} 7.7$ ).

After the incubations and washing described, all sections were dipped in ice-cold water, air-dried, and stored for 24 to 48 hours at $4^{\circ} \mathrm{C}$ in sealed slide boxes with Drierite capsules. The sections and tritiated plastic standards (American Radiolabeled Chemicals, St. Louis, MO) were apposed to Hyperfilm- ${ }^{3} \mathrm{H}$ (Amersham, Arlington Heights, IL) in x-ray cassettes. Optimum exposure times for $5-\mathrm{HT}_{1 \mathrm{~A}}$ receptors were 8.5 weeks for the prefrontal cortex and 2.5 weeks for the hippocampus. Optimum exposure times for $5-\mathrm{HT}_{2 \mathrm{~A}}$ receptors were 14 weeks for the prefrontal cortex and 16 weeks for the hippocampus. Films were developed with Kodak D-19 developer and fixed with Kodak Rapid Fix.

Autoradiographic images of radioligand binding were measured with the Microcomputer Controlled Imaging Device (MCID, Imaging Research, Inc., St. Catharines, Ontario, Canada). Using Nissl-stained sections and the descriptions of Pazos et al. (1987a, 1987b) and Duvernoy (1988), digital templates were drawn to correspond to various hippocampal regions and cortical laminar isodensity bands located on gyri and were superimposed on autoradiographic images by MCID. The total binding of $\left[{ }^{3} \mathrm{H}\right] 8-\mathrm{OH}-\mathrm{DPAT}$ was quantified because nonspecific binding was virtually indistinguishable from the film background. Images of the total and nonspecific binding of $\left[{ }^{3} \mathrm{H}\right]$ ketanserin were digitized and superimposed, and nonspecific binding was digitally subtracted from total binding to yield specific binding. The specific binding of $\left[{ }^{3} \mathrm{H}\right] 8-\mathrm{OH}-\mathrm{DPAT}$ and $\left[{ }^{3} \mathrm{H}\right] \mathrm{ket}-$ anserin was $>95 \%$ and approximately $75 \%$, respectively, of total binding. For both autoradiographic assays, the specific binding values presented are the average of the triplicate sections that were assayed. For $\left[{ }^{3} \mathrm{H}\right] 8-\mathrm{OH}-D P A T$ and $\left[{ }^{3} \mathrm{H}\right]$ ketanserin binding in a representative layer of prefrontal cortex, the average coefficient of variance for all subjects was 0.067 and 0.113 , respectively. The autoradiographic receptor assays were performed with one concentration of radioligand, and, as such, the specific 
binding values reflect receptor number $\left(B_{\max }\right)$ and/or receptor affinity $\left(K_{d}\right)$.

For quantitative densitometry, gray level transmittance per pixel was converted to relative optical density by MCID and expressed as fmol of radioligand bound per mg protein by calibrating to images from coexposed tritiated plastic standards (American Radiolabeled Chemicals, St. Louis, MO). The plastic standards were previously calibrated by coexposure with sections of brain mash containing known amounts of tritium and protein (Geary et al. 1985; Lowry et al. 1951). An autoradiographic density value, expressed as fmol bound per $\mathrm{mg}$ protein, is an averaged value for all the pixels in a sample window drawn over a region of interest.

\section{Data Analysis and Statistics}

Analysis of covariance (ANCOVA) was used to control subjects and suicide victims with major depression. The covariates included age of the subjects, time from death to freezing tissue (postmortem interval in hours), and the time the tissues were stored in the freezer (storage in months). Bonferroni corrections were used to test for statistically significant effects between the two subject groups (a $p$ value of .05 was divided by the number of anatomical subregions being examined in a particular brain region to calculate the appropriate $p$ value for statistical significance). Receptor data also were statistically analyzed using rank-ordered nonparametric methods, and the statistical results were essentially identical to those observed using parametric methods (data not included).

Independent sample $t$-tests were used to compare the groups on age, postmortem interval, and storage time. Pearson's correlation coefficients were calculated to evaluate relationships between subject age, postmortem interval, storage time, and radioligand binding to the $5-\mathrm{HT}_{1 \mathrm{~A}}$ or $5-\mathrm{HT}_{2 \mathrm{~A}}$ receptors. Correlations were com-
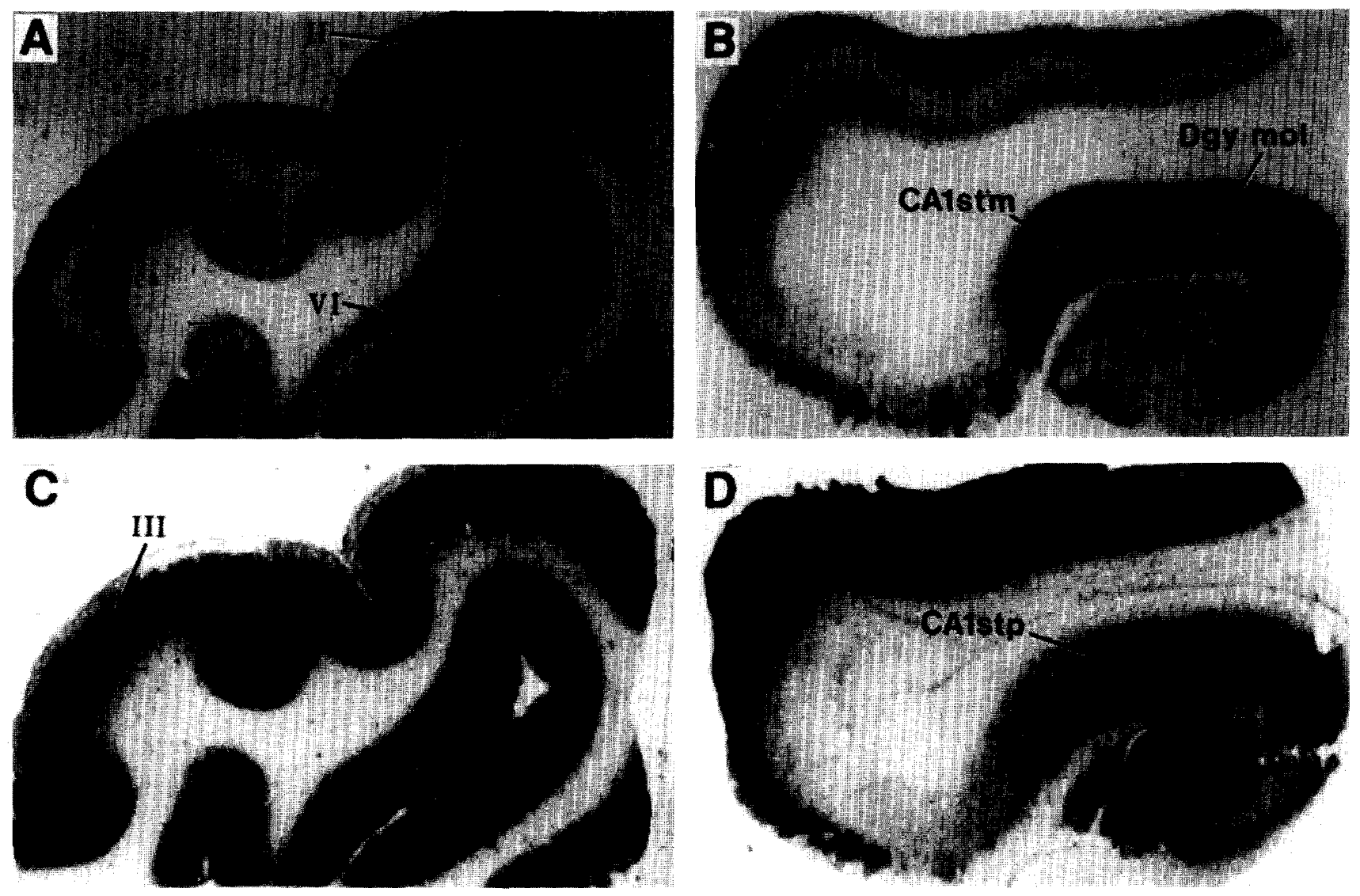

Figure 1. Digitized autoradiograms of total binding of $\left[{ }^{3} \mathrm{H}\right] 8-\mathrm{OH}-\mathrm{DPAT}$ and $\left[{ }^{3} \mathrm{H}\right]$ ketanserin in prefrontal cortex (area 10) and hippocampus of a control subject. $\left[{ }^{3} \mathrm{H}\right] 8-\mathrm{OH}-\mathrm{DPAT}(2 \mathrm{nM})$ binding to $5-\mathrm{HT}_{1 \mathrm{~A}}$ receptors is depicted in the prefrontal cortex $(A)$ and hippocampus $(B) .\left[{ }^{3} \mathrm{H}\right]$ Ketanserin $(2 \mathrm{nM})$ binding to $5-\mathrm{HT}_{2 \mathrm{~A}}$ receptors is depicted in the prefrontal cortex $(C)$ and hippocampus $(D)$. The images were from adjacent sections $(10 \mu \mathrm{m})$ of the prefrontal cortex and hippocampus of a 62-yearold control subject (postmortem delay of 26 hours). Abbreviations: II, layer II; III, layer III; VI, layer VI; CA1stm, stratum moleculare in the CA1 region of the hippocampus; Dgy mol, stratum moleculare of the dentate gyrus; CA1stp, stratum pyramidale in the CA1 region of the hippocampus. 
puted for individual subject groups as well as for all subjects grouped together. All values reported are the mean \pm standard deviation.

\section{RESULTS}

\section{Serotonin $_{1 \mathrm{~A}}$ Receptors}

Serotonin $_{1 \mathrm{~A}}$ receptors were measured in the right prefrontal cortex (area 10; Figure 1A). There were no significant differences between either subject group regarding age [control subjects $(N=13): 53 \pm 18$ years, suicide victims with major depression $(N=13)$ : $52 \pm 19$ years] or postmortem interval (control subjects: $20 \pm 7$ hours, suicide victims: $15 \pm 6$ hours). However, storage time was significantly longer $(p<.05)$ for suicide victims $(30 \pm$ 11 months) than to control subjects ( $19 \pm 11$ months). There were no significant differences in $5-\mathrm{HT}_{1 \mathrm{~A}}$ receptors between control subjects and suicide victims with major depression (Table 2). Comparisons were made with and without adjusting for subject age, postmortem interval, and sample storage time in the freezer.

Serotonin $_{1 \mathrm{~A}}$ receptors were also measured in the hippocampus and adjacent parahippocampal gyrus of control subjects and suicide victims with major depression (Figure 1B). There were no significant differences between either subject group regarding age [control subjects
$(N=10): 56 \pm 18$ years, suicide victims with major depression $(N=10): 54 \pm 18$ years], or storage time [control subjects ( $23 \pm 17$ months); suicide victims ( $28 \pm 12$ months)]. However, the postmortem interval was significantly longer $(p<.05)$ for control subjects than for the suicide victims (control subjects: $21 \pm 6$ hours, suicide victims: $15 \pm 7$ hours). There were no significant differences in $5-\mathrm{HT}_{1 \mathrm{~A}}$ receptors between subject groups in the parahippocampal gyrus or in the dentate gyrus or the molecular or pyramidal layers of CA1 (Table 2). Comparisons were made with and without adjusting for subject age, postmortem interval, and sample storage time in the freezer. There was a $16 \%$ increase in $5-\mathrm{HT}_{1 \mathrm{~A}}$ receptors in the molecular layer of the dentate gyrus $(p=.027)$. However, this difference was not statistically significant following the appropriate Bonferroni correction.

\section{Serotonin $_{2 \mathrm{~A}}$ Receptors}

Serotonin $_{2 \mathrm{~A}}$ receptors were measured in several cortical layers in the right prefrontal cortex (area 10; Figure 1C). There were no significant differences between the two subject groups regarding age [control subjects $(N=9)$ : $57 \pm 18$ years; suicide victims with major depression $(N=$ 10): $55 \pm 19$ years] or postmortem interval (control subjects: $21 \pm 6$ hours; suicide victims: $16 \pm 6$ hours). However, storage time was significantly longer $(p<.05)$ for

Table 2. Serotinin ${ }_{1 \mathrm{~A}}$ Receptors in the Prefrontal Cortex (area 10) and Temporal Lobe of Control Subjects and Suicide Victims with Major Depression

\begin{tabular}{|c|c|c|c|c|c|c|c|}
\hline Region & & Group & Mean & SD & $F$ & df & $p$-Value \\
\hline Cortex & Layer 2 & $\begin{array}{l}\text { Control } \\
\text { Suicide }\end{array}$ & $\begin{array}{l}352 \\
343\end{array}$ & $\begin{array}{l}86 \\
81\end{array}$ & 0.01 & 1,21 & 0.921 \\
\hline Cortex & Layer 6 & $\begin{array}{l}\text { Control } \\
\text { Suicide }\end{array}$ & $\begin{array}{l}80 \\
67\end{array}$ & $\begin{array}{l}24 \\
20\end{array}$ & 2.00 & 1,21 & 0.172 \\
\hline Hippocampus & CA1 stratum moleculare & $\begin{array}{l}\text { Control } \\
\text { Suicide }\end{array}$ & $\begin{array}{l}696 \\
780\end{array}$ & $\begin{array}{r}78 \\
118\end{array}$ & 1.40 & 1,15 & 0.256 \\
\hline Hippocampus & CA1 stratum pyramidale & $\begin{array}{l}\text { Control } \\
\text { Suicide }\end{array}$ & $\begin{array}{l}1,067 \\
1,080\end{array}$ & $\begin{array}{l}88 \\
97\end{array}$ & 0.01 & 1,15 & 0.941 \\
\hline Hippocampus & $\begin{array}{l}\text { Dentate gyrus stratum } \\
\text { moleculare }\end{array}$ & $\begin{array}{l}\text { Control } \\
\text { Suicide }\end{array}$ & $\begin{array}{l}309 \\
358\end{array}$ & $\begin{array}{l}72 \\
82\end{array}$ & 6.03 & 1,15 & $0.027^{*}$ \\
\hline Hippocampus & $\begin{array}{l}\text { Dentate gyrus } \\
\text { polymorphic layer }\end{array}$ & $\begin{array}{l}\text { Control } \\
\text { Suicide }\end{array}$ & $\begin{array}{l}199 \\
208\end{array}$ & $\begin{array}{l}39 \\
46\end{array}$ & 1.12 & 1,15 & 0.307 \\
\hline Parahippocampal gyrus & Layer 2 & $\begin{array}{l}\text { Control } \\
\text { Suicide }\end{array}$ & $\begin{array}{l}547 \\
582\end{array}$ & $\begin{array}{r}118 \\
85\end{array}$ & 0.09 & 1,15 & 0.762 \\
\hline Parahippocampal gyrus & Layers $5+6$ & $\begin{array}{l}\text { Control } \\
\text { Suicide }\end{array}$ & $\begin{array}{l}142 \\
145\end{array}$ & $\begin{array}{l}31 \\
20\end{array}$ & 0.09 & 1,15 & 0.774 \\
\hline
\end{tabular}

\footnotetext{
Serotinin $_{1 \mathrm{~A}}$ receptors were autoradiographically measured with $\left[{ }^{3} \mathrm{H}\right] 8-\mathrm{OH}-\mathrm{DPAT}(2 \mathrm{nM})$, and nonspecific binding was measured in the presence of $10 \mu \mathrm{M}$ serotonin. Receptor values are expressed as $\mathrm{fmol} / \mathrm{mg} \mathrm{protein}$ and represent the mean and standard deviation (SD) of 13 control subjects and 13 suicide victims in the cortex and 10 control subjects and 10 suicide victims in the hippocampus. Analysis of covariance was used to compare sample groups. The covariates included: age of the subjects, time from death to freezing the tissue, and the time the tissues were stored in the freezer.

* Not significantly different from control population when using Bonferroni correction.
} 
suicide victims ( $30 \pm 10$ months) than for control subjects ( $21 \pm 10$ months). There were no significant differences in $5-\mathrm{HT}_{2 \mathrm{~A}}$ receptors between control subjects and suicide victims with major depression, with or without adjustment for subject age, postmortem interval, and storage time (Table 3). Furthermore, there was no significant difference in the $5-\mathrm{HT}_{1 \mathrm{~A}} / 5-\mathrm{HT}_{2 \mathrm{~A}}$ receptor ratio in layers II or VI of the prefrontal cortex (data not shown).

Serotonin $_{2 \mathrm{~A}}$ receptors also were measured in the hippocampus of control subjects and suicide victims with major depression (Figure 1D). Age, postmortem interval, and storage time are listed for $5-\mathrm{HT}_{1 \mathrm{~A}}$ receptors in the hippocampus. There were no statistically significant differences in 5- $\mathrm{HT}_{2 \mathrm{~A}}$ receptors between subject groups in the molecular or pyramidal layers of CA1 or the dentate gyrus (Table 3). Comparisons were made with and without adjusting for subject age, postmortem interval, and storage time. There was a $26 \%$ increase in $5-\mathrm{HT}_{2 \mathrm{~A}}$ receptors in layer 2 of the prefrontal cortex $(p=0.045)$. However, this difference was not statistically significant after the appropriate Bonferroni correction.

Pearson's correlation coefficients were calculated to evaluate the relationships between subject age, postmortem interval, or storage time and radioligand binding to the $5-\mathrm{HT}_{1 \mathrm{~A}}$ or $5-\mathrm{HT}_{2 \mathrm{~A}}$ receptors. Groups were pooled for the correlational analyses as there were no significant differences detected by covariate analysis in receptor values between suicide victims and control subjects. For $5-\mathrm{HT}_{1 \mathrm{~A}}$ receptors only, there was a trend for a negative correlation in the prefrontal cortex between storage time and layer $6(r=-.397, p=.037)$ and a positive correlation in the hippocampus between storage time and the pyramidal layer of CA1 $(r=.449, p=.036)$. However, these differences were not statistically significant after the appropriate Bonferroni correction.

\section{DISCUSSION}

In the present study, there were no significant differences between control subjects and suicide victims with major depression regarding $5-\mathrm{HT}_{1 \mathrm{~A}}$ or $5-\mathrm{HT}_{2 \mathrm{~A}}$ receptors in the right prefrontal cortex (area 10) or hippocampus. Retrospective psychiatric assessments of the suicide victims indicated that all of the subjects met DSM-III-R criteria for a current episode of major depression at the time of death. Retrospective psychiatric assessments performed on nearly all of the comparison subjects indicated that they were psychiatrically normal at the time of death and had no lifetime history of major depression. In addition, none of the subjects in either group met criteria for psychoactive substance use disorder at the time of death.

The lack of significant differences between suicide victims with major depression and control subjects suggests that $5-\mathrm{HT}_{1 \mathrm{~A}}$ and $5-\mathrm{HT}_{2 \mathrm{~A}}$ receptors in these specific areas may not play a role in the pathophysiology of suicide and/or major depression. However, the ultimate involvement of serotonin receptors and the related

Table 3. Serotinin $2 \mathrm{~A}$ Receptors in the Prefrontal Cortex (area 10) and Hippocampus of Control Subjects and Suicide Victims with Major Depression

\begin{tabular}{|c|c|c|c|c|c|c|}
\hline Region & Group & Mean & SD & $F$ & df & $p$-Value \\
\hline \multicolumn{7}{|l|}{ Cortex } \\
\hline \multirow[t]{2}{*}{ Layer 1} & Control & 124 & 61 & 0.60 & 1,14 & 0.451 \\
\hline & Suicide & 132 & 38 & & & \\
\hline \multirow[t]{2}{*}{ Layer 2} & Control & 84 & 40 & 4.84 & 1,14 & $0.045^{*}$ \\
\hline & Suicide & 106 & 63 & & & \\
\hline \multirow[t]{2}{*}{ Layer 3} & Control & 184 & 87 & 0.04 & 1,14 & 0.846 \\
\hline & Suicide & 178 & 58 & & & \\
\hline \multirow[t]{2}{*}{ Layer 5} & Control & 156 & 74 & 1.37 & 1,13 & 0.262 \\
\hline & Suicide & 171 & 48 & & & \\
\hline \multirow[t]{2}{*}{ Layer 6} & Control & 48 & 19 & 0.77 & 1,13 & 0.396 \\
\hline & Suicide & 56 & 16 & & & \\
\hline \multicolumn{7}{|l|}{ Hippocampus } \\
\hline \multirow[t]{2}{*}{ Ca1 stratum molecular } & Control & 61 & 28 & 2.60 & 1,15 & 0.128 \\
\hline & Suicide & 81 & 33 & & & \\
\hline \multirow[t]{2}{*}{ CA1 stratum pyramidal } & Control & 72 & 40 & 4.26 & 1,15 & 0.057 \\
\hline & Suicide & 96 & 43 & & & \\
\hline \multirow[t]{2}{*}{ Dentate gyrus } & Control & 41 & 33 & 1.80 & 1,14 & 0.201 \\
\hline & Suicide & 58 & 37 & & & \\
\hline
\end{tabular}

Serotinin $_{2 \mathrm{~A}}$ receptors were autoradiographically measured with [ $\left.{ }^{3} \mathrm{H}\right]$ ketanserin $(2 \mathrm{nM})$, and non-specific binding was measured in the presence of $1 \mu \mathrm{M}$ mianserin. Receptor values are expressed as $\mathrm{fmol} / \mathrm{mg} \mathrm{protein}$ and represent the mean and the standard deviation (SD) of 9 control subjects and 10 suicide victims in the cortex and 10 control subjects and 10 suicide victims in the hippocampus. Analysis of covariance was used to compare sample groups.

*Not significantly different from control population when using Bonferroni correction. 
transducer proteins and second-messenger systems in major depression or suicide cannot be assessed solely by in vitro autoradiographic measurement of receptors. The role of 5- $\mathrm{HT}_{1 \mathrm{~A}}$ and $5-\mathrm{HT}_{2 \mathrm{~A}}$ receptors in the pathophysiology of major depression awaits more conclusive imaging studies using selective serotonin receptor ligands in living humans with major depression.

There are some potential limitations to studies of postmortem tissue in general and to this study in particular. These limitations include: the use of subjects with a prior history of psychoactive substance use disorder, the age of subjects, the postmortem interval, the psychotropic medication history of the subjects, the use of blood samples in the toxicological assessment of the presence of psychotropic drugs, and the size of the sample population.

Subject age, postmortem interval, and storage time of tissue samples in the freezer may influence serotonin receptor subtypes in the human brain. For example, several studies have established an age-related decrease in $5-\mathrm{HT}_{1 \mathrm{~A}}$ and $5-\mathrm{HT}_{2 \mathrm{~A}}$ receptors in numerous brain regions. Serotonin ${ }_{1 \mathrm{~A}}$ receptors are negatively correlated with age in the temporal, cingulate, and frontal cortex, in the hippocampus, and in the pre- and postcentral gyri (Middlemiss et al. 1986; Dillon et al. 1991). Similarly, 5- $\mathrm{HT}_{2 \mathrm{~A}}$ receptors are negatively correlated with age in the hippocampus and frontal cortex (Wong et al. 1984; Cheetham et al. 1988; Arango et al. 1990; Gross-Isseroff et al. 1990; Blin et al. 1993). Hence, an ANCOVA with age as a covariate was used in the current study to compare receptor values in the two subject groups. Although the present study did not detect any relationship between age and any of the binding values measured, these prior studies strongly indicate that age is negatively correlated with $5-\mathrm{HT}_{1 \mathrm{~A}}$ and $5-\mathrm{HT}_{2 \mathrm{~A}}$ receptor subtypes. The relatively small sample size in the present study may explain the lack of interaction between age and the receptors.

Receptors may undergo degradation during the postmortem interval time between death and freezing of tissue samples or during the time that samples are stored at $-80^{\circ} \mathrm{C}$. In the current study, the postmortem interval was significantly longer (more than 6 hours) in control subjects than suicide victims. However, in agreement with Lowther et al. (1994), there was no significant correlation between postmortem interval and any receptor values in either the prefrontal cortex or the hippocampus. Furthermore, storage time did not have a consistent effect on receptor values. Although the radioligand binding domains of these receptors appear to be stable between 4 and 28 hours postmortem and during tissue storage at $-80^{\circ} \mathrm{C}$, both postmortem interval and storage time were used as covariates in statistical comparisons of subject groups.

Alcohol dependence, which involves the physiological symptoms of tolerance and withdrawal, has a significant effect on monoamine markers in postmortem studies of human brain tissue. For example, chronic long-term alcoholics with thiamin deficiency exhibit a substantial decrease in the number of serotonergic neurons in the brainstem (Halliday et al. 1993). Additionally, the number of noradrenergic neurons in the locus coeruleus is significantly lower in alcohol-dependent subjects (Arango et al. 1994). In the present study, care was taken to exclude control subjects or suicide victims with current diagnoses of either alcohol dependence or alcohol abuse. The study included one suicide victim and one control subject who met diagnostic criteria for alcohol abuse 5 and 2 years, respectively, prior to their deaths. These two subjects did not meet the criteria for alcohol abuse during the last 5 and 2 years of their lives. In contrast to the DSM-III-R criteria for alcohol dependence, alcohol abuse does not involve the physiological symptoms of tolerance and withdrawal, and there is no current evidence that remote alcohol abuse results in lasting changes in the number of serotonin receptors. One suicide victim met diagnostic criteria for alcohol dependence 15 years before death but was in full remission during the last 15 years of life. Excluding the two subjects with a prior history of alcohol abuse and the one subject with a prior history of alcohol dependence did not significantly alter the results of the statistical comparisons of receptor values for the control and suicide groups (data not shown).

One suicide victim in this study had a medical history of Parkinson's disease. Although serotonin neurons in the median (but nor dorsal) raphe are significantly lower in subjects with Parkinson's disease (Halliday et al. 1990), this subject was included in the receptor studies inasmuch as a recent study demonstrated that the risk of suicide in patients with Parkinson's disease is no greater than in the background population (Stenager et al. 1994). There was no significant difference in the results obtained for receptors whether the subject with Parkinson's disease was included or not (data not shown).

The use of some antidepressant medications may influence some types of serotonin receptors in brain tissue. In animal studies, the chronic administration of amitriptyline, imipramine, or tranylcypromine decreases the number of $5-\mathrm{HT}_{2 \mathrm{~A}}$ receptors in the cerebral cortex (Kellar et al. 1981; Burnet et al. 1994). However, neither monoamine oxidase inhibitors nor selective serotonin reuptake inhibitors decrease the number of $5-\mathrm{HT}_{1 \mathrm{~A}}$ receptors (Hensler et al. 1991). In the present study, although three of the 13 subjects with major depression had a prescription for an antidepressant drug in the month prior to death, blood and urine samples from only one of these subjects (used only in the $5-\mathrm{HT}_{1 \mathrm{~A}}$ receptor studies) revealed the presence of the antidepressant drug imipramine. However, toxicological assessment in these subjects based on blood or urine samples, as compared to samples of brain tissue, could underestimate the 
presence of psychotropic medications. The exclusion of the three subjects with recent prescriptions for an antidepressant drug did not significantly alter the results of statistical comparisons of receptor values for the control and suicide groups (data not shown). The observation that few of the suicide victims with major depression were receiving antidepressant medication is consistent with reports that most depressed individuals who commit suicide are not taking antidepressant drugs at the time of death (Isacsson et al. 1994; Marzuk et al. 1995).

Numerous studies have examined $5-\mathrm{HT}_{2 \mathrm{~A}}$ receptors in the prefrontal cortex of suicide victims. In five studies in which no psychiatric information was available on the suicide victims, there were four reports of a higher and one report of lower $5-\mathrm{HT}_{2 \mathrm{~A}}$ receptors in the prefrontal cortex than in age-matched nonsuicide subjects [Stanley and Mann 1983 (areas $8+9$ ); Mann et al. 1986 (areas $8+9$ ); Arora and Meltzer 1989 (areas $8+9$ ); Arango et al 1990 (area 9); Gross-Isseroff et al 1990 (Areas 8,9$)$ ]. In contrast, in eight studies of suicide victims with some documentation of depressive or psychotic symptoms, two studies reported an increase in $5-\mathrm{HT}_{2 \mathrm{~A}}$ receptors [Hrdina et al. 1993 (area 9); Laruelle et al. 1993 (area 10)], and six studies detected no change in $5-\mathrm{HT}_{2 \mathrm{~A}}$ receptors [(Owen et al. 1983, 1986 (areas $8+9$ ); Crow et al. 1984 (area 10); Cheetham et al. 1988 (Area 10); Lowther et al. 1994 (area 10); Arranz et al. 1994 (areas $9+10+11)$ ]. The study by Lowther et al. (1994) is most notable for demonstrating no change in $5-\mathrm{HT}_{2 \mathrm{~A}}$ receptors in depressed suicide victims, as six forebrain areas were examined in over 70 pairs of control subjects and suicide victims. These authors evaluated such variables as psychiatric diagnosis (endogenous depression or depressive syndromes vs. other diagnoses), recent history of antidepressant medication, and method of suicide (violent vs. nonviolent) and found no relationship between these variables and the number of $5-\mathrm{HT}_{2 \mathrm{~A}}$ receptors. Our results agree with those of Lowther et al. (1994), suggesting that well-controlled studies will find no significant differences in $5-\mathrm{HT}_{1 \mathrm{~A}}$ or $5-\mathrm{HT}_{2 \mathrm{~A}}$ receptors in the prefrontal cortex (area 10) or hippocampus of suicide victims with major depression compared to normal control subjects.

Two studies have examined $5-\mathrm{HT}_{2 \mathrm{~A}}$ receptors in the prefrontal cortex of subjects with major depression, most of whom did not die by suicide [McKeith et al. 1987 (area 10); Yates et al. 1990 (area 9)]. McKeith et al. (1987) did not observe a statistically significant difference in $5-\mathrm{HT}_{2 \mathrm{~A}}$ receptors in major depression, but Yates et al. (1990) noted a significant increase in $5-\mathrm{HT}_{2 \mathrm{~A}}$ receptor number in four subjects with major depression. A methodological complication of these two studies involves the measurement of the nonspecific binding of $\left[{ }^{3} \mathrm{H}\right]$ ketanserin with nonradioactive ketanserin. Ketanserin has a high affinity for $\alpha_{1}$-adrenergic receptors, in addition to $5-\mathrm{HT}_{2 \mathrm{~A}}$ receptors (Hoyer et al. 1987).
Serotonin $_{2 \mathrm{~A}}$ receptors also have been examined in the hippocampus of suicide victims. An earlier study by Cheetham et al. (1988) reported a significant decrease in the number of $5-\mathrm{HT}_{2 \mathrm{~A}}$ receptors in the hippocampus of suicide victims with depression. However, a later study by this group (Lowther et al. 1994) and by others (Gross-Isseroff et al. 1990; Joyce et al. 1993) failed to replicate the observation of Cheetham et al. (1988). In the present study, there was a trend for an increase in $\left[{ }^{3} \mathrm{H}\right]$ ketanserin binding in the hippocampus of suicide victims. However this difference did not reach statistical significance (Table 3). It is possible that $\left[{ }^{3} \mathrm{H}\right]$ ketanserin may be interacting with $5-\mathrm{HT}_{2 \mathrm{C}}$ as well as $5-\mathrm{HT}_{2 \mathrm{~A}}$ receptors in the hippocampus and that the relative nonselectivity of this radioligand is obscuring the results. Studies with cloned receptors, however, indicate that this possibility is unlikely because ketanserin is approximately 26 -fold more selective for the $5-\mathrm{HT}_{2 \mathrm{~A}}$ than $5-\mathrm{HT}_{2 \mathrm{C}}$ receptor (Choudhary et al. 1992). Barring the nonselective interaction of $\left[{ }^{3} \mathrm{H}\right]$ ketanserin with other serotonin receptor subtypes in the hippocampus, the findings reported in the present study support the conclusion that $5-\mathrm{HT}_{2 \mathrm{~A}}$ receptors in the hippocampus are unchanged in suicide victims with major depression.

Several groups have examined $5-\mathrm{HT}_{1 \mathrm{~A}}$ receptors in various brain regions of suicide victims and matched controls. However, as with $5-\mathrm{HT}_{2 \mathrm{~A}}$ receptors no clear picture has emerged. Matsubara et al. (1991) detected an increase in $5-\mathrm{HT}_{1 \mathrm{~A}}$ receptors in the prefrontal cortex (areas 8 and 9) of suicide victims. No psychiatric information was available on these subjects, and the increase in $5-\mathrm{HT}_{1 \mathrm{~A}}$ receptors was seen only in male suicide victims dying from drug overdose or carbon monoxide poisoning (defined as nonviolent) versus suicide victims dying from gunshot wounds, hanging, stabbing, or falls (defined as violent). In a recent report, Arango et al. (1995) reported increases in radioligand binding to $5-\mathrm{HT}_{1 \mathrm{~A}}$ receptors confined to the ventrolateral (areas 45 and 46) but not other areas (e.g., 8, 9, 11, 12, 24, 32) of the prefrontal cortex of suicide victims. Although psychiatric information was not available for either suicide victims or control subjects, the subject pairs were carefully matched for age, gender, and postmortem interval (Arango et al. 1995). Three other studies report no change in $5-\mathrm{HT}_{1 \mathrm{~A}}$ receptors in the prefrontal cortex, even when suicide victims were classified as either depressed or not depressed [Cheetham et al. 1990 (area 10); Dillon et al. 1991 (areas 8 and 9); Arranz et al. 1994 (areas $9+10+$ 11)]. Thus, the findings of the present study in area 10 of depressed suicide victims dying primarily of violent means are consistent with other reports of no change in $5-\mathrm{HT}_{1 \mathrm{~A}}$ receptors in this cortical area from suicide victims.

Serotinin $_{1 \mathrm{~A}}$ receptors have also been examined in the hippocampus of suicide victims. Although Dillon et al. (1991) detected no change in the binding of $\left[{ }^{3} \mathrm{H}\right] 8-\mathrm{OH}-$ DPAT to $5-\mathrm{HT}_{1 \mathrm{~A}}$ receptors in the hippocampus, Joyce et al. 
(1993) reported an increase in these sites in the stratum pyramidale (CA1) of hippocampus of suicide victims. Consistent with the observations of Dillon et al. (1991), 5- $\mathrm{HT}_{1 \mathrm{~A}}$ receptors in the hippocampus in the present study were unchanged in suicide victims with major depression.

There are some limitations to the mentioned studies of serotonin receptors in postmortem brain tissue from suicide victims and subjects with depressive disorders. Some studies provide limited or no psychiatric information on subjects (Stanley and Mann 1983; Mann et al. 1986; Arora and Meltzer 1989; Gross-Isseroff et al. 1990; Arango et al. 1990, 1994). Other studies have relied on unstructured clinical interviews and/or medical records to derive a psychiatric diagnosis compatible with DSMIII (McKeith et al. 1987; Yates et al. 1990; Hrdina et al. 1993), DSM-III-R (Joyce et al. 1993), or an unidentified diagnostic system (Crow et al. 1984; Owen et al. 1986; Arranz et al. 1994). Some previous studies also have included a range of psychiatric diagnoses under the general heading of depression, including bipolar disorder (McKeith et al. 1987; Yates et al. 1990; Hrdina et al. 1993), schizoaffective disorder (Crow et al. 1984), and an unspecified reference to depressive syndrome or symptoms (Lowther et al. 1994; Arranz et al. 1994). Finally, many previous studies lack information on current or previous psychoactive substance use disorders. Hence, the previous findings may be complicated by the presence of a range of psychiatric diagnoses in the subjects studied. It is plausible that different serotonin receptor subtypes are involved in the pathophysiology of different psychiatric disorders in suicide victims.

The current study was designed to control several of the diagnostic issues outlined, which may account for the varied results between research groups regarding serotonin receptors in suicide. In the present study, for example, all of the suicide victims had a current DSM-III-R diagnosis at the time of death of major depression, there were no current psychoactive substance use disorders for suicide victims or comparison subjects, and comparison subjects were found to be psychiatrically normal. In addition, almost none of the suicide victims were taking antidepressant medication in the weeks before death. In this study, any putative differences in serotonin receptors between the two subject groups may be due to either the cause of death (suicide) or the psychiatric diagnosis (major depression), or an interaction of these two factors. An inherent limitation in any study using only depressed suicide victims and normal controls is that major depression and suicide may have opposite, and thereby experimentally undetectable, effects on a neuropharmacological marker. The precise influence of suicide and major depression would best be addressed by a study including the following four groups of subjects: (1) normal control subjects; (2) subjects with major depression who did not die of suicide; (3) suicide victims with major depression; and (4) suicide victims without major depres- sion. Tissues are being collected to explore these four groups of subjects.

In conclusion, the evidence for widespread changes in cortical $5-\mathrm{HT}_{1 \mathrm{~A}}$ and $5-\mathrm{HT}_{2 \mathrm{~A}}$ receptors in suicide or major depression appears uncertain. The current results suggest that the number of $5-\mathrm{HT}_{1 \mathrm{~A}}$ and $5-\mathrm{HT}_{2 \mathrm{~A}}$ receptors in the right prefrontal cortex (area 10) or hippocampus are not altered in suicide victims with major depression. The most consistent change in serotonin receptors in brain tissue from suicide victims has been an increase in $5-\mathrm{HT}_{2 \mathrm{~A}}$ receptors in the dorsolateral prefrontal cortex (areas $8+$ 9). Further postmortem studies of major depression and suicide may be warranted in brain regions where metabolic and blood flow studies indicate anomalies in major depression. For example, subjects with major depression have abnormal metabolism and blood flow in the left prefrontal cortex (orbitofrontal and dorsolateral regions) (Drevets et al. 1992; Biver et al. 1994; Mann et al. 1996). To establish a role for serotonin receptors in the forebrain in major depression and suicide, it will be of interest to measure $5-\mathrm{HT}_{1 \mathrm{~A}}$ and $5-\mathrm{HT}_{2 \mathrm{~A}}$ receptors, as well as the serotonin transporter postmortem in the precise areas where metabolic disturbances have been reported.

\section{ACKNOWLEDGMENTS}

Supported by PHS Grants MH45488 (CAS) and MH41684 (HYM) and a grant from the American Suicide Foundation. HYM is a recipient of a USPHS Research Career Scientist Award MH47808. The authors give special thanks to the coroner, deputy coroners, toxicology laboratory, and staff of the Cuyahoga County Coroner's Office, Cleveland, $\mathrm{OH}$. The assistance of Pierluigi Gambetti, M.D., in the neuropathological examination of tissue samples in greatly appreciated. The authors also acknowledge helpful discussions with Gregory A. Ordway, Ph.D., and Gay Kitson, Ph.D. We are grateful to Philip Cola, Leena Khaitan, Katherine J. Morrison, and Deval A. Shah for excellent administrative and technical assistance.

\section{REFERENCES}

Alexander BS, Wood MD (1988): [ $\left.{ }^{3} \mathrm{H}\right] 8-\mathrm{OH}-\mathrm{DPAT}$ labels the 5-hydroxytryptamine uptake recognition site and the $5-\mathrm{HT}_{1 \mathrm{~A}}$ binding site in the rat striatum. J Pharm Pharmacol 40:888-891

American Psychiatric Association (1987): Diagnostic and Statistic Manual of Mental Disorders, ed. 3, revised. Washington, DC, APA

Andreasen NC, Endicott J, Spitzer RL, Winokur G (1977): The family history method using diagnostic criteria. Reliability and validity. Arch Gen Psychiatry 34:1229-1235

Arango V, Ernsberger P, Marzuk PM, Chen J-S, Tierney H, Stanley M, Reis DJ, Mann JJ (1990): Autoradiographic demonstration of increased serotonin $5 \mathrm{HT}_{-}$and $\beta$-adrenergic receptor binding sites in the brain of suicide victims. Arch Gen Psychiatry 47:1038-1047

Arango V, Underwood MD, Mann JJ (1994): Fewer pig- 
mented neurons in the locus coeruleus of uncomplicated alcoholics. Brain Res 650:1-8

Arango V, Underwood MD, Gubbi AV, Mann JJ (1995): Localized alterations in pre- and postsynaptic serotonin binding sites in the ventrolateral prefrontal cortex of suicide victims. Brain Res 688:121-133

Arató M, Demeter E, Rihmer Z, Somogyi E (1988): Retrospective psychiatric assessment of 200 suicides in Budapest. Acta Psychiatr Scand 77:454-456

Arora RC, Meltzer HY (1989): Serotonergic measures in the brains of suicide victims: $5-\mathrm{HT}_{-2}$ binding sites in the frontal cortex of suicide victims and control subjects. Am J Psychiatry 146:730-736

Arranz B, Eriksson A, Mellerup E, Penge P, Marcusson J (1994): Brain 5- $\mathrm{HT}_{1 \mathrm{~A}}, 5-\mathrm{HT}_{1 \mathrm{D}}$, and 5- $\mathrm{HT}_{2}$ receptors in suicide victims. Biol Psychiatry 35:457-463

Åsberg M, Schalling D, Traskman-Bendz L, Wagner A (1987): Psychobiology of suicide, impulsivity, and related phenomena. In Meltzer HY (ed), Psychopharmacology: Third Generation of Progress, New York, Raven, pp $655-666$

Biver F, Lotstra F (1994): Frontal and parietal metabolic disturbances in unipolar depression. Biol Psychiatry 36: 381-388

Blier P, de Montigny C (1994): Current advances and trends in the treatment of depression. Trends Pharmacol Sci 15:220-226

Blin J, Baron JC, Dubois B, Crouzel C (1993): Loss of brain $5-\mathrm{HT}_{2}$ receptors in Alzheimer's disease. In vivo assessment with positron emission tomography and $\left[{ }^{18} \mathrm{~F}\right]$ setoperone. Brain 116:497-510

Burnet PWJ, Michelson D, Smith MA, Gold PW, Sternberg EM (1994): The effect of chronic imipramine administration on the densities of $5-\mathrm{HT}_{1 \mathrm{~A}}$ and $5-\mathrm{HT}_{2}$ receptors and the abundancies of $5-\mathrm{HT}$ receptor and transporter mRNA in the cortex, hippocampus and dorsal raphe of three strains of rat. Brain Res 638:311-324

Cheetham SC, Crompton MR, Katona C, Horton RW (1988): Brain 5- $\mathrm{HT}_{-2}$ receptor binding sites in depressed suicide victims. Brain Res 443:272-280

Cheetham SC, Crompton MR, Katona C, Horton RW (1990): Brain $5-\mathrm{HT}_{-}{ }_{1}$ binding sites in depressed suicides. Psychopharmacology 102:544-548

Choudhary MS, Craigo S, Roth BL (1992): Identification of receptor domains that modify ligand binding to 5-hydroxytryptamine ${ }_{2}$ and 5-hydroxytryptamine ${ }_{1 C}$ serotonin receptors. Mol Pharmacol 42:627-633

Coppen A (1967): The biochemistry of affective disorders. $\mathrm{Br}$ J Psychiatry 113:1237-1264

Crow TJ, Cross AJ, Cooper SJ, Deakin JFW, Ferrier IM, Johnson JA, Joseph MH, Owen F, Poulter M, Lofthouse R, Corsellis JAN, Chanbers DR, Blessed G, Perry EK, Perry RH, Tomlinson BE (1984): Neurotransmitter receptors and monoamine metabolites in brain of patients with Alzheimer-type dementia and depression, and suicides. Neuropharmacology 23:1561-1569

Cusack B, Nelson A, Richelson E (1994): Binding of antidepressants to human brain receptors: Focus on newer generation compounds. Psychopharmacology 114:559-565

Delgado PL, Charney DS, Price LH, Aghajanian GK, Landis
H, Henninger G (1990): Serotonin function and the mechanism of antidepressant action. Arch Gen Psychiatry $47: 411-418$

Dillon KA, Gross-Isseroff R, Israeli M, Biegon A (1991): Autoradiographic analysis of serotonin $5-\mathrm{HT}_{-1 \mathrm{~A}}$ receptor binding in the human brain postmortem: Effects of age and alcohol. Brain Res 554:56-64

Drevets WC, Videen TO, Price JL, Preskorn SH, Carmichael ST, Raichle ME (1992): A functional anatomical study of unipolar depression. J Neurosci 12:3628-3641

Duvernoy HM (1988): The Human Hippocampus. An Atlas of Applied Anatomy, Munich, JF Bergman Verlag

Geary WA II, Toga AW, Wooten GF (1985): quantitative film autoradiography for tritium: Methodological considerations. Brain Res 337:99-108

Grimsley SR, Jann MW (1993): Paroxetine, sertraline, and fluvoxamine: New selective serotonin reuptake inhibitors. Clin Pharmacol 11:930-957

Gross-Isseroff R, Salama D, Israeli M, Biegon A (1990): Autoradiographic analysis of age-dependent changes in serotonin $5-\mathrm{HT}_{-2}$ receptor of the human brain postmortem. Brain Res 507:208-215

Halliday GM, Blumbergs PC, Cotton RGH, Blessing WW, Geffen LB (1990): Loss of brainstem serotonin- and substance P-containing neurons in Parkinson's disease. Brain Res 510:104-107

Halliday G, Ellis J, Heard R, Caine D, Harper C (1993): Brainstem serotonergic neurons in chronic alcoholics with and without the memory impairment of Korsakoff's psychosis. J Neuropath Exp Neurol 52:567-579

Hensler JG, Kovachich GB, Frazer A (1991): A quantitative autoradiographic study of serotonin $_{1 A}$ receptor regulation; Effect of 5,7-dihydroxytryptamine and antidepressant treatments. Neuropsychopharmacology 4:131-144

Hoyer D, Pazos A, Probst A, Palacios JM (1986): Serotonin receptors in human brain. I. Characterization and autoradiography of $5-\mathrm{HT}_{1 \mathrm{~A}}$ sites. Apparent absence of $5-\mathrm{HT}_{1 \mathrm{~B}}$ recognition sites. Brain Res 376:85-96

Hoyer D, Vos P, Closse A, Palacios JM, Davies H (1987): $\left[{ }^{3} \mathrm{H}\right]$ Ketanserin labels 5 - $\mathrm{HT}_{-2}$ receptors and $\alpha{ }_{-1}$-adrenoceptors in human and pig brain membranes. NaunynSchmiedeberg's Arch Pharmacol 335:226-230

Hrdina PD, Demeter E, Vu TB, Sotonyi P, Palkovits M (1993): 5-HT uptake sites and $5-\mathrm{HT}_{2}$ receptors in brain of antidepressant-free suicide victims/depressives: Increases in 5- $\mathrm{HT}_{2}$ sites in cortex and amygdala. Brain Res 614:37-44

Isacsson G, Holmgren P, Wasserman D, Bergman U (1994): Use of antidepressants among people committing suicide in Sweden. British Med J 308:506-509

Joyce JN, Shane A, Lexow N, Winokur A, Casanova MF, Kleinman JE (1993): Serotonin uptake sites and serotonin receptors are altered in the limbic system of schizophrenics. Neuropsychopharmacology 8:315-336

Kellar KJ, Cascio CS, Butler JA, Kurtzke RN (1981): Differential effects of electroconvulsive shock and antidepressant drugs on serotonin- ${ }_{2}$ receptors in rat brain. Eur J Pharmacol 69:515-518

Laruelle M, Abi-Dargham A, Casanova MF, Toti R, Weinberger DR, Kleinman JE (1993): Selective abnormalities 
of prefrontal serotonergic receptors in schizophrenia. Arch Gen Psychiatry 50:810-818

Lesage AD, Boyer R, Grunberg F, Vanier C, Morissette R, Menard-Buteau C, Loyer M (1994): Suicide and mental disorders: A case-control study of young men. Am J Psychiatry 151:1063-1068

Lowry OH, Rosebrough NJ, Farr AL, Randall RJ (1951): Protein measurement with Folin phenol reagent. J Biol Chem 193:265-270

Lowther S, DePaermentier F, Crompton MR, Katona CLE, Horton RW (1994): Brain 5- $\mathrm{HT}_{2}$ receptors in suicide victims: Violence of death, depression and effects of antidepressant treatment. Brain Res 642:281-289

Mann JJ, Stanley M, McBride PA, McEwen BS (1986): Increased serotonin-2 and $\beta$-adrenergic receptor binding in the frontal cortices of suicide victims. Arch Gen Psychiatry 43:954-959

Mann JJ, Malone KM, Diehl DJ, Perel J, Cooper TB, Mintun MA (1996): Demonstration in vivo of reduced serotonin responsivity in the brain of untreated depressed patients. Am J Psychiatry 153:174-182

Marzuk PM, Tardiff K, Leon AC, Hirsch CS, Stajic M, Hartwell N, Portera L (1995): Use of prescription psychotropic drugs among suicide victims in New York City. Am J Psychiatry 152:1520-1522

Matsubara S, Arora RC, Meltzer HY (1991): Serotonergic measures in suicide brain: $5-\mathrm{HT}_{1 \mathrm{~A}}$ binding sites in frontal cortex of suicide victims. J Neural Transm 85:181-194

McKeith IG, Marshall EF, Ferrier IN, Armstrong MM, Kennedy WN, Perry RH, Perry EK, Eccleston D (1987): 5-HT receptor binding in post-mortem brain from patients with affective disorder. J Affective Dis 13:67-74

Middlemiss DN, Palmer AM, Edel N, Bowen DM (1986): Binding of the novel serotonin agonist 8-hydroxy-1-(di- n-propylamino)-tetralin in normal and Alzheimer brain. J Neurochem 46:993-996

Owen F, Cross AJ, Crow TJ, Deakin JFW, Ferrier IM, Lofthouse $\mathrm{R}$, Poulter $\mathrm{M}$ (1983): Brain 5- $\mathrm{HT}_{-}$receptors and suicide. Lancet 2:1256

Owen F, Chambers DR, Cooper SI, Crow TJ, Johnson JA, Lofthouse R, Poulter M (1986): Serotonergic mechanisms in brains of suicide victims. Brain Res 362:185-188

Pazos A, Probst A, Palacios JM (1987a): Serotonin receptors in the human brain-III. Autoradiographic mapping of serotonin-1 receptors. Neuroscience 21:97-122

Pazos A, Probst A, Palacios JM (1987b): Serotonin receptors in the human brain-IV. Autoradiographic mapping of serotonin-2 receptors. Neuroscience 21:123-139

Shopsin B, Gershon S, Goldstein M, Friedman E, Wilk S (1975): Use of synthesis inhibitors in defining a role for biogenic amines during imipramine treatment in depressed patients. Psychopharmacol Commun 1:239-249

Spitzer RL, Endicott J (1978): Schedule for affective disorders and schizophrenia (SADS), ed 3, New York, New York State Psychiatric Institute

Stanley M, Mann JJ (1983): Increased $5 \mathrm{HT}_{-2}$ binding sites in frontal cortex of suicide victims. Lancet 1:214-216

Stenager EN, Wermuth L, Stenager E, Boldsen J (1994): Suicide in patients with Parkinson's disease. An epidemiological study. Acta Psychiatr Scand 90:70-72

Wong DF, Wagner HN Jr, Dannals RF, Links JM (1984): Effects of age on dopamine and serotonin receptors measured by positron emission tomography in the living human brain. Science 226:1394-1396

Yates M, Leake A, Candy JM, Fairbairn AF, McKeith IG, Ferrier IN (1990): $5-\mathrm{HT}_{-2}$ receptor changes in major depression. Biol Psychiatry 27:489-496 